\title{
Effect of Fatty Acids on Reproductive Performance of Ruminants
}

\author{
Herrera-Camacho, José1, Soberano-Martínez, Alejandra ${ }^{1}$, Orozco Durán, \\ Karlos Edmundo², Aguilar-Pérez, Carlos² and Ku-Vera, Juan Carlos² \\ ${ }^{1}$ Instituto de Investigaciones Agropecuarias y Forestales \\ Universidad Michoacana de San Nicolás de Hidalgo \\ ${ }^{2}$ Campus de Ciencias Biológicas y Agropecuarias \\ Universidad Autónoma de Yucatán \\ México
}

\section{Introduction}

Different types of fats have been utilized in an attempt to improve reproductive function in ruminant animals. Fatty acids derived from plants and oil seeds have exerted a major impact on reproductive performance, some of the most common sources include sunflower, linseed, cottonseed, rapeseed and soyabean. Animal fat (tallow) and calcium salts of saturated fatty acids may escape in a significant percentage rumen hydrogenation to be incorporated into adipose tissue and milk. Fish by-products contain a high proportion of polyunsaturated fatty acids (PUFAs) and pass without being altered in the rumen exerting no effects on rumen fermentation. Each dietary source of fat varies regarding composition of specific fatty acids (Table 1 ).

Early studies of the effect of fat in the ration on reproductive performance were carried out by Burr \& Burr (1930), who observed that fat deficiency in the ration of growing rats induced alterations in ovulation rate and on the onset of oestrus, while lipid supplementation reestablished reproductive performance of the females, coining the concept of essential fatty acids. In later studies, research was aimed at evaluating the effect of fat supplementation in different animal species both ruminant and non-ruminant, on reproductive aspects such as the establishment of puberty (Smith et al., 1989), semen production (Castellano et al., 2010), maternal recognition of pregnancy (Abayasekara \& Wathes, 1999, Filley et al., 2000, Lopes et al., 2009) by means of the suppression of luteolytic signals (Mattos et al., 2000), restart of ovarian activity after parturition (de Fries et al., 1998), follicle development, quality of oocytes (Staples \& Thatcher, 2005; Bilby et al., 2006c), and of the embryo (Cerri et al., 2009), modification in the mechanism of synthesis and secretion of hormones involved in reproductive processes (Staples et al., 1998) and on production aspects such as quality of milk (Rego et al., 2004; Bernal et al., 2010) or meat (Wood et al., 2003). Due to the fact that some fatty acids (FA) are essential for mammals and to the role of fatty acids on reproductive processes, it is possible that cattle reproduction will be influenced more by the type of lipids consumed than for the total lipid intake. This is particularly important since ruminants hydrogenate PUFAs in the rumen, limiting the amount of PUFAs that are absorbed from the small intestine (Thatcher \& Staples, 2007, 
Santos et al., 2008, Doreau et al., 2011). However, it is possible that some specific PUFAs may pass intact the reticulo-rumen and be absorbed from the small intestine, allowing in this way the improvement of reproductive efficiency directly on the target tissue of the reproductive system of the female (autocrine or paracrine) or by an indirect effect mediated by the endocrine system (Staples \& Thatcher, 2005).

\begin{tabular}{|c|c|c|c|c|c|c|c|}
\hline Fat source & & & & tty acid & & & \\
\hline & C14:0 & C16:0 & C16:1 & C18:0 & C18:1 & C18:2 & C18:3 \\
\hline & Myristic & Palmitic & $\begin{array}{l}\text { Palmit- } \\
\text { oleic }\end{array}$ & Stearic & Oleic & Linoleic & Linolenic \\
\hline Tallow & 3 & 25 & 3 & 18 & 43 & 3.8 & $<1$ \\
\hline Yellow grease & 2 & 21 & 4 & 11 & 44 & 14 & $<1$ \\
\hline $\begin{array}{l}\text { Energy Booster } \\
100^{1}\end{array}$ & 3 & 40 & 1 & 41 & 10 & 2 & $<1$ \\
\hline $\begin{array}{l}\text { Megalac: } \\
\text { EnerG-II }^{1}\end{array}$ & 1 & 50 & $<1$ & 4 & 36 & 8 & $<1$ \\
\hline Megalac- $\mathbf{R}^{\mathbf{1}}$ & 1 & 36 & $<1$ & 4 & 26 & 29 & 3 \\
\hline Canola oil & $<1$ & 4 & $<1$ & 2 & 63 & 19 & 9 \\
\hline Cottonseed oil & 1 & 23 & $<1$ & 3 & 18 & 54 & 1 \\
\hline Flaxseed oil & $<1$ & 5 & 1 & 3 & 20 & 16 & 55 \\
\hline $\begin{array}{l}\text { Extruded } \\
\text { Linseed }\end{array}$ & $<1$ & 7.6 & & 5.2 & 20 & 14.5 & 51.3 \\
\hline Rapeseed oil & $<1$ & 5 & $<1$ & 2 & 54 & 22 & 11 \\
\hline Safflower oil & $<1$ & 7 & $<1$ & 2 & 12 & 78 & $<1$ \\
\hline Soyabean oil & $<1$ & 11 & $<1$ & 4 & 23 & 54 & 8 \\
\hline Sunflower oil & $<1$ & 7 & $<1$ & 5 & 19 & 68 & 1 \\
\hline $\begin{array}{l}\text { Menhaden fish } \\
\text { oil }^{2}\end{array}$ & 7 & 16 & 8 & 3 & 12 & 1 & 2 \\
\hline
\end{tabular}

Table 1. Fatty acid composition of selected dietary fat sources. ${ }^{1}$ Commercial preparations considered partially inert in the rumen; ${ }^{2}$ Also contain 14\% C20:5 and 9\% C22:6 (Thatcher \& Staples, 2007).

Several studies have shown that PUFAs of the $\omega-3$ family such as eicosapentaenoic acid $(\mathrm{C} 20: 5, \omega-3)$ and docosahexaenoic acid (C22:6, $\omega-3)$ suffer insignificant biohydrogenation in the rumen (Thatcher \& Staples, 2007). These fatty acids are usually found in feedstuffs derived from fish (and other marine products), such as the oil and the meal which are considered non essential since they can be synthesized from linoleic acid $(\omega-3)$, and apparently play an important role in animal performance (Thatcher \& Staples, 2007). Furthermore, lipid supplements partially resistant to biohydrogenation in the rumen have been developed such as calcium salts of long chain fatty acids (Ca-LCFA) with the aim of increasing the amount of unsaturated FA which can be absorbed by limiting biohydrogenation (Mattos et al., 2000). PUFAs act as mediators in a series of processes in several reproductive tissues, including fluidity of cell membrane, intracellular signaling and susceptibility to oxidative damage (Wathes et al., 2007). Changes in chain length, degree of unsaturation and position of the double bonds in the acil chain of fatty acids may have a major impact on reproductive function and play a role in livestock reproduction (Mattos et 
al., 2000). Potential mechanisms may include increment of energy density of the ration (Ferguson et al., 1990), even when for some workers (Williams \& Amstalden, 2010), the effect of fat supplementation on reproduction is independent of the energy density of ration or of changes in live weight of animals. Considering all the above described, the aim of this review is to examine some of the reproductive processes in the bovine and ovine females which could be regulated or modified by the inclusion of lipids in the ration.

\section{Effect of lipid supplementation on pregnancy rate}

Incorporation of lipids in rations for dairy cattle usually increases energy density of ration and improves lactation and reproductive performance (Funston, 2004). However, when they are supplied in early lactation, frequently there is a reduction in feed intake due to a reduction in dry matter digestibility and to an increase in energy of greater availability, so when lipids are supplied in the early postpartum period, there is little alteration in the energy status of the animal even when a higher energy density ration is consumed (Santos et al., 2008).

Then, if dietary fat does not alter the energy status of dairy cows, reproductive response results more from the supply of some fatty acids, than from the effect of the energy supply per se (Staples et al., 1998, Williams \& Amstaldem, 2010).

There are several studies that report a better reproductive performance in cows fed supplementary lipids. In this respect, Staples et al. (1998), showed that lipid consumption exerted a positive effect on reproductive aspects in dairy cows (Table 2). In beef cattle, the same trend has been observed. It is in this context that, de Fries et al. (1998) reported that Brahman cows consuming 5.2\% lipids in the ration showed a trend towards an increase in pregnancy rate than those cows which consumed only $3.7 \%$ lipids in the ration. Ferguson et al. (1990) observed a 2.2 times increase in the possibility of pregnancy in lactating cows consuming $0.5 \mathrm{~kg}$ lipids per day. In another study, it was demonstrated that grazing cows supplemented with fat, pregnancy rate at first service was $16 \%$ higher than in cows which did not receive fat in the ration (Bader et al., 2000).

Bellows et al., (2001) observed that supplementation with safflower seed, soyabeans, or sunflower seed $(4.7,3.8$ and $5.1 \%$ fat in the ration, respectively) for the last 65 days before calving increased subsequent pregnancy rates $(94 \%, 90 \%$ and $91 \%$, respectively) of first-calf beef heifers compared with the control (79\%) that received only $2.4 \%$ fat in the ration. In another study Bellows et al., (2001), using good quality forage and a higher amount of fat in the ration $(6.5 \%)$ during 68 days before calving, was unable to improve pregnancy rates relative to a control ration $(2.2 \%$ fat), this result indicates that when adequate nutrients are available, the effect of supplemental fat may be masked.

Grazing Holstein cows which were supplemented for 103 days, as from day 10 post-partum, with two sources of bypass fat Megalac plus 3\% (MP; $0.4 \mathrm{~kg} /$ day, containing Ca salts of palm fatty acids and Ca salts of methionine hydroxy analogue) and Megapro Gold (MPG; $1.5 \mathrm{~kg} /$ day, containing Ca salt of palm fatty acids, extracted rapeseed meal and whey permeate), MPG increased $(P<0.05)$ conception rate to first service compared to control group (CG). Conception rate to first service was similar $(P=0.14)$ on MP compared to CG. For pregnancy to second service, CG had a higher $(P<0.05)$ conception rate than MP. There were no significant differences between treatments in overall pregnancy rate, services per conception, number of cows served in the first three weeks of the breeding season or the 6- 
weeks in-calf rate. Comparing the combined fat treatments to CG resulted in a higher $(P<0.05)$ conception rate to first service for the fat treatments but no significant difference in overall pregnancy rate (McNamara et al., 2003).

\begin{tabular}{|l|l|l|l|}
\hline Reference & Fat source & $\begin{array}{l}\text { Percent } \\
\text { inclusion }\end{array}$ & Pregnancy rate \\
\hline Fergunson et al., 1990 & Ca-Palm oil & $2.0 \%$ & 591 \\
\hline Sklan et al.,1991 & Ca-Palm oil & $2.6 \%$ & 82 \\
\hline Scott et al., 1995 & Ca-Palm oil & $1 \mathrm{lb} \mathrm{d}-1$ & 98 \\
\hline Garcia-Bojalil et al., 1998 & Ca-Palm oil & $2.2 \%$ & 86 \\
\hline Son et al., 1996 & Tallow & $3 \%$ & 62 \\
\hline Espinoza et al., 2010 & Tallow & $9.5 \%$ & Herd A 70; Herd B 55\% \\
\hline Frajblat and Butler, 2003 & Energy Booster & $1.7 \%$ & 86 \\
\hline Petit et al., 2001 & Flaxseed & $17 \%$ & 87 \\
\hline Ambrose et al., 2006 & Flaxseed & $9 \%$ & 481 \\
\hline Ambrose et al., 2006b & Flaxseed & $9 \%$ & 261 \\
\hline Fuentes et al., 2007 & Extruded Linseed & $1.7 \mathrm{kgd}^{-1}$ & 39 \\
\hline McNamara et al., 2003 & MegaPro Gold & $3.3 \mathrm{lb} \mathrm{d}-1$ & 54 \\
\hline Juchem et al., 2004 & Soy + Trans C18:1 & $1.5 \%$ & 341 \\
\hline Cullens, 2005 & Megalac-R & $2 \%$ & 581 \\
\hline Aguilar-Pérez et al., 2009 & ByFat ${ }^{\circledR}$ & $1.8 \%$ & 33 \\
\hline Espinoza et al., 2010 & Megalac & $9.6 \%$ & Herd A 80; Herd B 58\% \\
\hline $\begin{array}{l}{ }^{\circledR} \\
\text { Castañeda-Gutierrez }\end{array}$ et 2005 & Ca-CLA & $0.3 \mathrm{lb} \mathrm{d}-1$ & 81 \\
\hline Bernal-Santos et al., 2003 & Ca-CLA & $0.3 \mathrm{lb} \mathrm{d}-1$ & 42 \\
\hline Bruckental et al., 1989 & Fish meal & $7.3 \%$ & 72 \\
\hline Armstrong et al., 1990 & Fish meal & $1.8 \mathrm{lb} \mathrm{d}-1$ & 64 \\
\hline Carroll et al., 1994 & Fish meal & $3.5 \%$ & 89 \\
\hline Burke et al., 1997 & Fish meal & 2.8 & 41 \\
\hline
\end{tabular}

Table 2. Reproductive performance of beef cows supplemented with fat in the ration. ${ }^{1}$ First insemination (Adapted from Thatcher \& Staples, 2007).

In another study, Aguilar-Pérez et al., (2009) observed that pregnancy rate of $F_{1}$ (Holstein $x$ Zebu) cows grazing under tropical conditions in Mexico, was not affected by supplementation with bypass fat $(33.3 \%)$, relative to a control group $(41.7 \%)$ at 90 days postpartum. In conclusion, fat supplementation increased conception rate to first service but did not significantly affect the proportion of cows pregnant at the end of the breeding season, these results suggest that the higher quality of the forage supplied in the different seasons that the trial lasted, may have been a factor that masked the effect of fat supplementation. Juchem et al. (2010) evaluated the effect of supplementation before and after parturition with Ca-LCFA of palm oil or with a mixture of linoleic and trans-octadecenoic acids and observed that cows fed PUFAs showed a higher pregnancy rate than those supplemented with palm oil at 27 and 41 days (37.9 vs $28.6 \%$ and 35.5 vs $25.8 \%$, respectively) after artificial insemination. Recently, Lopes et al. (2009) fed Nellore cows with $0.1 \mathrm{~kg} \mathrm{cow}^{-1} \mathrm{day}^{-1}$ of PUFAs and observed that pregnancy rate was improved. In this respect, Mattos et al. (2000) suggested that the positive 
effect of fat on fertility may not be due to improvement in energy balance of the cows but rather to the specific effect of some dietary fatty acids on the physiology of the hypothalamushypophysis-ovary axis and even the uterus.

In a review of previous studies in which conjugated linoleic acids (CLA) were supplemented to dairy cows during early lactation, de Veth et al. (2009) demonstrated that the probability of pregnancy increases in $26 \%$ when CLA are increased in the ration and that the optimum CLA amount is $10.0 \mathrm{~g} \mathrm{~d}^{-1}$, after which the beneficial effects are reduced. It is possible that the positive effect of lipid supplementation may be due to specific fatty acids (Staples \& Thatcher, 2005), and the absorption of unsaturated FA in ruminants is limited due microbial biohydrogenation in the rumen (Lopes et al., 2009). Some studies have evaluated the possibility that unsaturated FA intake, particularly those of the $n-6$ (linoleic acid) and n-3 (alinolenic, eicosapentaenoic, docosahexaenoic acids) families, may have some influence on reproduction in cows, even when reports in the literature are not always consistent (Santos et al., 2008). In this respect, when cows were fed $0.75 \mathrm{~kg}$ of linseed rich in $\alpha$-linolenic acid ( $n$ $3)$, or sunflower rich in linoleic acid (n-6), pregnancy rate tended to increase in cows of the first treatment (Ambrose et al., 2006a).

In other studies, no response was observed with linseed (Fuentes et al., 2008). Similarly, feeding $n-3$ fatty acids from fish oil in the form of Ca-LCFA did not improve pregnancy rate postpartum at first service in beef cows when compared to supplementation with beef tallow (Juchem, 2007) or with Ca-LCFA from palm oil (Silvestre, quoted by Santos et al., 2008), even when pregnancy rate at second service postpartum was higher in cows fed $n-3$ fatty acids (Silvestre, quoted by Santos et al., 2008). In grazing $F_{1}$ (Bos taurus x Bos indicus) cows, Aranda-Ávila et al. (2010) observed a $15.4 \%$ increase in pregnancy rate when cows were supplemented with corn oil, relative to a control group (54.5 vs $41.7 \%$ respectively) after 35 day supplementation; however, differences were not statistically significant. It is possible that the poor response observed in those studies may be due to an increase in milk production along with a loss of body weight, which occurs in greater or lesser degree in cows during the early postpartum period (Sklan et al., 1994).

\section{Effect of lipid supplementation on the hypothalamus-hypophysis-ovary axis}

The major objective of cow-calf enterprises is to produce one calf per cow annually. Thus, management strategies that enhance reproductive performance of milk and beef cows are beneficial to the productivity of cow-calf operations. Previous studies reported that utilization of dietary fat as a nutraceutical, particularly PUFAs, positively influenced reproductive function in both milk and beef cows (Williams \& Stanko, 2000). Furthermore, these positive effects were independent of the additional energy contribution from the PUFAs sources (Funston, 2004). Different mechanisms have been proposed by means of which fat supplementation may affect functioning of the hypothalamus-hypophysis-ovary axis. Early work in this respect suggested that fat supplementation may affect secretion of reproductive and metabolic hormones and further research demonstrated that fat addition to the ration modified ovarian activity in heifers and adult cows postpartum.

The mechanism (or mechanisms) by which dietary fat improves reproductive performance has not been elucidated. Several hypotheses have been proposed: 1) an amelioration of a negative energetic balance, thus leading to an earlier return to oestrus postpartum and, therefore, improved fertility; 2) an increase in steroidogenesis favorable to improved 
fertility; 3) manipulation of insulin so as to stimulate ovarian follicle development; and 4) a stimulation or inhibition of the production and release of $\mathrm{PGF}_{2 \alpha}$, which influences the persistence of the corpus luteum (Staples et al., 1998)

\subsection{Hormonal secretion and lipid metabolites}

Some studies showed that dietary fat supplementation in dairy heifers increased circulating concentrations of progesterone (Talavera et al., 1985), and enhanced lifespan of induced corpus luteum during early postpartum in beef cows (Williams, 1989; Ryan et al., 1995). Other studies suggest that when lipids are included in the ration of cows to increase energy density, caloric balance is improved which directly influences hypophysis-gonadal activity postpartum (Harrison et al., 1995), increasing, in principle, the amplitude and frequency of secretion of luteinizing hormone (LH) in animals (Sklan et al., 1994). In this respect, de Luna et al. (1982), reported an increase in the secretion of luteinizing hormone in ovariectomized cows treated with GnRH and supplemented with beef tallow. In sheep, secretion of luteinizing hormone in response to the injection of $\mathrm{GnRH}$ at day 10 of the oestrus cycle was greater in Pelibuey sheep supplemented with Ca-LCFA from palm oil during 30 days than in the control group (Espinoza et al., 1997).

Other studies, using isocaloric and isonitrogenous diets in cows of poor body condition indicated that the increase in dietary fat consumption augmented the number of follicles of medium-size by 1.5- to 5-fold within 3 to 7 weeks and these changes occurred coincident with changes in serum insulin, growth hormone and intraovarian insulin-like growth factor (IGF-1) (Wehrman et al., 1991; Ryan et al., 1992; Thomas et al., 1997). Table 3 summarizes the effects of dietary fat supplementation on follicular physiology and growth as observed in different studies.

\begin{tabular}{|c|c|}
\hline Reference & Effect \\
\hline $\begin{array}{l}\text { Wehrman et al., 1991; Ryan et al., 1992; } \\
\text { Hightshoe et al., 1991; Lucy et al., 1991; } \\
\text { Thomas \& Williams, 1996; Thomas et al., 1997; } \\
\text { Lammoglia et al., 1996; Stanko et al., 1997; de } \\
\text { Fries et al., } 1998\end{array}$ & $\begin{array}{l}\text { Increased number of medium-sized } \\
\text { follicles (polyunsaturated fat }> \\
\text { saturated and highly polyunsaturated } \\
\text { fat effects) }\end{array}$ \\
\hline Lucy et al., 1989, 1991 & $\begin{array}{l}\text { Milk cows supplemented with Ca- } \\
\text { LCFA palm oil, the basal level of LH } \\
\text { was increase }\end{array}$ \\
\hline Wehrman et al., 1991; Ryan et al., 1992 & $\begin{array}{l}\text { Increased granullosa cell progesterone } \\
\text { production in vitro, increased follicular } \\
\text { fluid progesterone }\end{array}$ \\
\hline Lopes et al., 2009, Salas-Razo et al., 2011 & $\begin{array}{l}\text { Cows supplemented with rumen inert } \\
\text { polyunsaturated fat had greater mean } \\
\text { serum progesterone concentrations } \\
\text { compared with control }\end{array}$ \\
\hline Ryan et al., 1992; Thomas \& Williams, 1996 & No effect on superovulation rate \\
\hline $\begin{array}{l}\text { de Fries et al., 1998; Bilby et al., 2006a; } \\
\text { Garnsworthy et al., } 2008\end{array}$ & $\begin{array}{l}\text { Increased number of large follicles; } \\
\text { increased size of largest follicle }\end{array}$ \\
\hline
\end{tabular}

Table 3. Summary of the effect of dietary fat supplementation in cattle on ovarian follicular growth and steroid production. (Modified from Williams \& Amstalden, 2010) 
On the other hand, it has been shown that hiperlipidic rations supplied both to dairy as well as to beef cows, induced and increase in the levels of blood cholesterol, as it was observed by Hightshoe et al. (1991) in cows supplemented postpartum with Ca-LCFA from palm oil. Similar results, were reported in Angus and Hereford cows which consumed a supplement which contained $125 \mathrm{~g}$ of Ca-LCFA from palm oil (Espinoza et al., 1995), in Chinampas (Bos taurus) cows consuming Ca-LCFA from palm oil or beef tallow (Espinoza-Villavicencio et al., 2010); this is particularly important since cholesterol is the main precursor for progesterone synthesis in the corpus luteum as well as of other steroid hormones at the follicular level (Childs et al., 2008c). Thus, when supplementation with protected fats from rumen biohydrogenation is augmented, it is possible to increase concentration of plasma progesterone in cows (Lopes et al., 2009), which is associated positively with pregnancy rate (Santos et al., 2008). When endometrial secretions are modified (Gray et al., 2001) changes are induced in endometrial architecture which are fundamental for the appropriate development of the embryo (Wang et al., 2007). Nonetheless, in other studies, no response has been observed of fat supplementation on progesterone synthesis. In this respect, Robinson et al. (2002), using cows fed a ration rich in linoleic acid showed a reduction of up to $50 \%$ in the serum levels of progesterone between days 4 and 8 of the oestrus cycle, while those cows consuming a ration rich in linolenic acid showed a lower concentration of this hormone, but in days 4 and 15 of the oestrus cycle (Robinson et al., 2002). Recent work (Huante, 2010), demonstrated that secretion of progesterone in Brahman cows with low body condition at calving and during the postpartum (2.0 points, in the scale 1-5) was unaffected by supplementation with oilseeds with $60 \%$ of unsaturated fatty acids, relative to the control group $(0.065 \pm 0.013$ vs $0.054 \pm 0.013 \mathrm{ng} / \mathrm{ml}$, respectively). These results suggest that due to the low body condition, the cow uses feed energy for its maintenance and not for reproductive processes. Those results suggest that the above mentioned fatty acid, exert different effects in the synthesis of ovarian steroids (Hinckley et al., 1996). Childs et al. (2008b) fed beef heifers a ration enriched with fish oil $(n-3)$ and even when no increase in serum progesterone was achieved at day 7 of the oestrus cycle, they postulated that there was evidence of a greater synthesis of progesterone during the whole oestrus cycle due to the increase in the serum concentration of cholesterol and to the greater size of the corpus luteum.

While in sheep, concentration of progesterone in the follicular fluid was greater than in sheep which consumed the ration enriched with $n-3$ fatty acids, than those which were fed with a greater amount of $n-6$ fatty acids (Wonnacott et al., 2010). Some in vitro studies have demonstrated that progesterone metabolism can be inhibited by high concentrations (300 $\mu \mathrm{M})$ of $\alpha$-linolenic acid in the culture media (Piccinato et al., 2010). This is perhaps related to the fact that certain PUFAs may also increase serum concentration of insulin and this in turn, reduce hepatic expression of some enzymes of the cythocrome $\mathrm{P}_{450}$ complex which catabolize progesterone (Lemley et al., 2008). Oestradiol, another hormone derived from cholesterol has stimulatory effects on the uterine secretion of $\mathrm{PGF}_{2 \alpha}$ (Knickerbocker et al. 1986) and can increase sensibility of the corpus luteum to prostaglandins by intensifying its regression (Howard et al., 1990). Previous studies demonstrate that intra-abomasal infusion of yellow fat induced a reduction in blood levels of oestradiol between days 15 and 20 of the oestrus cycle, compared to cows which were infused with glucose intra-abomasally. The relationship between dietary fatty acids and synthesis of steroid hormones may be direct through a direct effect on steroidogenesis (acute regulatory protein of steroids; STAR, cythocrome P450 protein, family 11; subfamily A polypeptide enzyme 1; CYP11A1) etc. or 
indirectly through prostaglandins. STAR plays a fundamental role in the synthesis of steroid hormones (Stocco et al., 2005). In previous work, it has been observed that in beef heifers there was a reduction in the concentration of arachidonic acid in the endometrial tissue when they were fed n-3 PUFAs (Childs et al., 2008a; Childs et al., 2008b). On the other hand, there is evidence that supplementation with linoleic acid $(n-6)$ increased uterine secretion of $\mathrm{PGF}_{2 \alpha}$ (Cullens, 2005), which could derive in a greater availability of arachidonic acid in the endometrium. Under such conditions it could be speculated that a possible way to act of the $n-3$ and $n-6$ fatty acids in steroidogenesis is by reducing or increasing the availability of arachidonic acid, respectively and as a consequence, the expression of RNAm for STAR synthesis.

\subsection{Lipids on ovarian activity}

These results suggest that another of the mechanisms by means dietary lipids may improve reproductive performance of cattle is influencing follicular development and ovulation. In this, respect, Lucy et al. (1991), replaced corn with Ca-LCFA from palm oil in the ration of dairy cows at calving, and increased the number of medium size follicles $(6-9 \mathrm{~mm})$ and of follicles greater than $15 \mathrm{~mm}$ within 25 days postpartum. Furthermore, the diameter of the greatest follicle was superior in cows fed Ca-LCFA from palm oil (18.2 vs $12.4 \mathrm{~mm}$ ). When this study was repeated with isocaloric diet, observed effects were similar (Lucy et al. 1993). The greatest increase in medium follicle populations occurred in response to plant oil consumption, which is likely a direct result of the effects of high levels of linoleic acid in the rumen. Maximum follicular growth responses to plant oil supplementation have occurred when plant oils were fed at 4 to $6 \%$ of dietary dry matter, with lesser increases observed at lower levels of added fat. Animal tallow, calcium salts of saturated fatty acids or fish oil have been shown to have less clear effects on follicular growth than plant-derived oils. Moreover, postpartum beef cows which calved in a very poor body condition (BCS of 3; 1-9 scale) were unable to develop medium or large follicles at a rate equal to those with a body condition score of 4 or greater after 3 weeks of fat consumption (Ryan et al., 1994).

The number of medium size follicles ( 5 to $10 \mathrm{~mm}$ ) was higher in beef cows which consumed feed with a greater content of PUFAs (Thomas et al., 1997) and in dairy cows which consumed a diet enriched with 5\% n-3 fatty acids derived from fish oil (Heravi-Moussavi et al., 2007). Similar results were observed in cows fed with diets enriched with n-3 or n-6 fatty acids (Robinson et al., 2002). Staples \& Thatcher (2005) summarized the effect of increasing lipids in the ration on the size of the dominant follicle: on average, the size of the dominant follicle was $3.2 \mathrm{~mm}$ greater than in females fed with some source of fat, which represents a 23\% increase. Other studies (Bilby et al., 2006d; Garnsworthy et al., 2008) showed that the size of the dominant follicle is increased in cows fed diets rich in PUFAs. In sheep, the use of Ca-LCFA from palm oil (El-Shahat \& Abo-El maaty, 2010) or from corn oil (Herrera et al., 2008) in the feed improved the number and size of the preovulatory follicles, as well as rate of ovulation and the superovulatory response in Pelibuey sheep (Herrera et al., 2008). These evidences demonstrate that consumption of lipids accelerate follicular growth (de Fries et al., 1998), which may influence the restart of ovulation postpartum, as it was shown by Marín-Aguilar et al. (2007) who observed that Holstein cows supplemented with plant oil (60\% PUFAs) reduced by 7 days the restart of ovarian activity relative to a control group. de Veth et al. (2009) observed that time at first ovulation in dairy cows was reduced by 8 days when they were supplemented with $8 \mathrm{~g} / \mathrm{d}$ of trans-10, cis-12 CLA. 


\section{Lipids and its effect on endometrial secretion of prostaglandins}

Studies in a variety of species have shown that dietary PUFAs can modulate prostaglandin synthesis and metabolism. Eicosanoids, comprising prostaglandins, thromboxanes, leukotrienes and lipoxins, are all synthesized from C20 fatty acids (Mattos et al., 2000). The most biologically active two series prostaglandins are derived from arachidonic acid, but the less active three series prostaglandins can be produced from eicosapentaenoic acid by the action of the same enzymes (Robinson et al., 2002).

Prostaglandins play an important role in reestablishing oestrus cycles both immediately after parturition and thereafter until conception. Prostaglandin $\mathrm{F}_{2 \alpha}\left(\mathrm{PGF}_{2 \alpha}\right)$ is responsible for uterine involution after parturition. The uterus releases $\mathrm{PGF}_{2 \alpha}$ during each oestrus to regress each new corpus luteum if the cow is not pregnant and initiate a new oestrus cycle. During the period of corpus luteum regression, concentrations of $\mathrm{PGF}_{2 \alpha}$ and progesterone are inversely related. If the cow does conceive, release of $\mathrm{PGF}_{2 \mathrm{a}}$ from the uterus is prevented in order to preserve the corpus luteum and maintain pregnancy (Funston \& Filley, 2002).

Linoleic acid is a substrate for the synthesis of $\mathrm{PGF}_{2 \mathrm{a}}$. Linoleic acid can be desaturated and elongated to arachidonic acid (C20:4,n-6), which is a precursor for $\mathrm{PGF}_{2 \mathrm{a}}$. Regulatory enzymes for this conversion include delta 6 desaturase and cyclooxygenase. Linoleic acid can inhibit prostaglandin synthesis by competitive inhibition with these key enzymes. Arachidonic, and two fatty acids found in fishmeal, eicosapentaenoic (C20:5) and docosahexanoic (C22:6), have been shown to inhibit cyclooxygenase activity as well. It is important to note that linolenic acid (C18:3) was also present in the endometrial prostaglandin synthesis inhibitor isolated by Thatcher et al. (1994), and that linolenic acid has been shown to be a strong inhibitor of prostaglandin synthesis (Mattos et al., 2000). The amount and probably type of particular fatty acids reaching the target tissues likely influence if prostaglandin synthesis is going to be stimulated or inhibited (Thatcher \& Staples, 2000).

Figure 1 shows the schematic metabolic pathway of dietary n-6 and n-3 PUFAs and potential mechanisms for regulation of $\mathrm{PGF}_{2 \alpha}$ secretion. Absorbed PUFAs are desaturated and elongated in organs such as the mammary gland, adipose tissue, testis, brain, placenta and the liver (of non-ruminants). Dietary PUFAs and their desaturation and elongation products are incorporated into phospholipids of the plasma membrane. The amount of each fatty acid incorporated depends on the amount of precursor present in the diet. External stimuli such as the binding of oxytocin (OT) to the oxytocin receptor (OTr) stimulates the activity of phospholipase A2 (PLA2) and phospholipase C (PLC), which cleave phospholipids from the plasma membrane and ultimately increase availability of diacylglycerol (DAG) and fatty acids for processing by prostaglandin $\mathrm{H}$ synthetase (PGHS). Eicosapentaenoic acid (EPA; C20:5, n-3) is processed by PGHS to generate prostaglandins of the 3 series. Arachidonic acid (AA; C20:4 n-6) can be processed by PGHS, epoxygenase and lipoxygenase to generate prostaglandins of the 2 series, epoxyeicosatrienoic acids (EETs), leukotrienes and hydroxyeicosatetraenoic acids (di-HETEs), respectively (Mattos et al., 2000).

In vitro studies have demonstrated that some $n-3$ (eicosapentaenoic and docosahexaenoic) fatty acids reduce biosynthesis of prostaglandins of the series 2 in cells and tissues (Mattos et al., 2003). Similarly, some isomers from conjugated linoleic acid inhibited synthesis of $\mathrm{PGF}_{2 \alpha}$ and the effect was independent of the concentration of linolenic acid and the ratio $n$ 6:n-3 (Harris et al., 2001). The above results are interesting due to the fact that most 


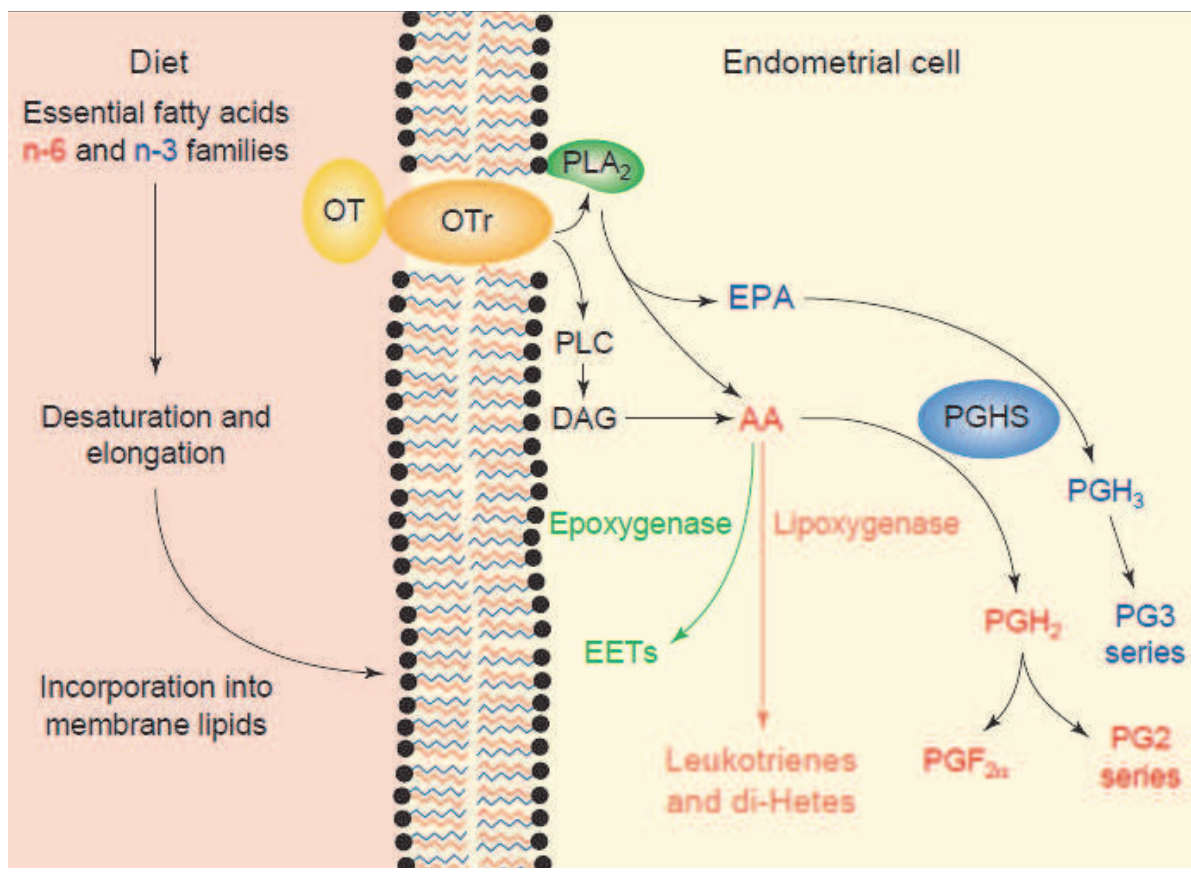

Fig. 1. Schematic representation of the metabolism of dietary n-6 and n-3 polyunsaturated fatty acids and potential mechanisms for regulation of $\mathrm{PGF}_{2 \alpha}$ secretion (Mattos et al., 2000).

embryonic losses in cattle occur during days 8-16 after artificial insemination (Sreenan et al., 2001), which leads to believe that some embryos may not reach the appropriate size at that moment to inhibit synthesis of $\mathrm{PGF}_{2 \alpha}$ for luteolysis to occur (Thatcher et al., 1994), showing the inability to inhibit luteolytic action by $\mathrm{PGF}_{2 \alpha}$ during the critical period of maternal recognition of pregnancy (Childs et al., 2008a). In this context, inhibition of the synthesis of $\mathrm{PGF}_{2 \alpha}$ could increase the rates of embryo survival and pregnancy (Binelli et al., 2001). PUFAs (n-3) such as eicosapentaenoic acid may inhibit uterine synthesis of $\mathrm{PGF}_{2 a}$ by competing with arachidonic acid by means of COX, or in the case of docosahexaenoic acid, by competence with arachidonic acid by phospholipase A2 enzymes (Mattos et al., 2000).

Fish meal has relatively high concentrations of eicosapentaenoic and docosahexaenoic acids, in such a way that their incorporation in the ration of cattle may reduce the synthesis of $\mathrm{PGF}_{2 \alpha}$ and delay regression of the corpus luteum, improving embryo survival and herd fertility (Staples et al., 1998)

Previous studies showed that the infusion of a fat source rich in linoleic acid (17\%) into the abomasum of lactating dairy cows resulted in a significant reduction in the release of PGFM, as measured in peripheral plasma, in response to an injection of oxytocin on day 15 of a synchronized oestrous cycle (Oldick et al., 1997). These results indicate that high concentrations of PUFAs in the diet can decrease endometrial secretion of prostaglandins. In this respect, in cows, fed with $n-3$ fatty acids derived from fish meal, a reduction was observed in endometrial secretion of arachidonic acid, increasing in this same tissue the levels of eicosapentaenoic acid and total n-3 fatty acids (Burns et al., 2003; Bilby et al., 2006b). Similar effects were observed in dairy cows which consumed increasing amounts of 
fish meal or Ca-LCFA from fish oil (Bilby et al. 2006a). Due to the addition of $n-3$ and $n-6$ in the phospholipid component of endometrium, it is possible that changes in the content of fatty acids in the endometrial tissue may modulate secretion of $\mathrm{PGF}_{2 \alpha}$ in cows (Santos et al., 2008). In further studies, Burns et al. (2003) reported an increase in eicosapentaenoic acid at day 18 postpartum, as well as a reduction in arachidonic acid in the caruncules of beef cows fed fish meal. In another study, supplementing the diet with fish oil during the periparturient period reduced uterine secretion of $\mathrm{PGF}_{2 \alpha}$ in lactating dairy cows. In this sense, beef heifers fed $n-3$ PUFAs reduced production of arachidonic acid in endometrial tissue, apparently due to the fact that linoleic acid must elongate and desaturate to form arachidonic acid using the same enzymes than for the synthesis of eicosapentaenoic acid, starting from a-linolenic acid (Coyne et al., 2008).

There is evidence that during the prepartum period, lipid supplementation with $30 \%$ fatty acids as linoleic acid (n-6) increased uterine secretion of $\mathrm{PGF}_{2 \alpha}$ (Cullens, 2005). Increase in the synthesis of $\mathrm{PGF}_{2 \alpha}$ when cows are fed $n-6$ fatty acids during the transition period before calving or during the early postpartum (puerperium), can increase the potential of the uterus and of the immune system to secrete eicosanoids, which have influence in postpartum uterine health and in the inmunocompetence of the cow (Santos et al., 2008).

Childs et al. (2008b) fed heifers with a diet rich in $n-6$ fatty acids (entire soyabeans) or $n-3$ fatty acids (fish oil) and observed that on day 15 of the oestrous cycle, serum concentration of PGFM metabolite was higher than in the first group. These results are interesting if it is considered that by stimulating secretion of $\mathrm{PGF}_{2 \alpha}$ during early postpartum uterine involution can be favored (Mattos et al., 2004) and reproductive efficiency is improved, since when cows were supplemented before calving with calcium salts rich in $n-6$ fatty acids the occurrence of postpartum diseases such as membrane retention, metritis and mastitis, was reduced (Cullens, 2005). Thus, both arachidonic acid, but as well precursors of this fatty acid, such as linoleic acid increase the production of series 2 prostaglandin, while $n-3$ fatty acids compete with arachidonic acid and therefore reduce synthesis of such prostaglandin. In studies carried out in vitro, addition of eicosapentaenoic acid to the culture media of endometrial cells of cows, reduced production of endometrial $\mathrm{PGF}_{2 \alpha}$ from 88 to $40 \%$, but this was reverted as the ratio of $n-6: n-3$ in the culture media was increased from 0 to $19 \%$ (Caldari-Torres et al., 2006). This observation is consistent with previous reports and suggest that the net inhibition of uterine $\mathrm{PGF}_{2 \alpha}$ synthesis by $n-3$ fatty acids may depend on the amount of $n-6$ fatty acids that reach the secretory tissue (Achard et al., 1997).

However, recent studies (Meier et al., 2009) showed that the bovine endometrial and trophoblastic tissues during short-term culture, incubated in a media supplemented with fatty acids: eicosapentaenoic (20:5-3; EPA), docosahexaenoic acids (22:6-3; DHA) or linoleic acids (C18:2-6; LIN), the release of $\mathrm{PGE}_{2}$ from 'pregnant' endometrium was higher $(\mathrm{P}=0.094)$ than from 'non-pregnant' endometrium, while $\mathrm{PGF}_{2 \alpha}$ concentrations were similar. Treatment with fatty acids had no effect on $\mathrm{PGF}_{2 \alpha}$ or $\mathrm{PGE}_{2}$ release from either pregnant or non-pregnant endometrium. The individual fatty acid treatments had no effect on the ratio of $\mathrm{PGF}_{2 \alpha}$ to $\mathrm{PGE}_{2}$ from trophoblast tissues, but when the data from the three fatty acid treatments were combined (EPA, DHA and LIN treatment groups) the ratio of $\mathrm{PGF}_{2 \alpha}$ to $\mathrm{PGE}_{2}$ was reduced $(P=0.026)$ when compared to the medium only. This result indicated that the ability of exogenous fatty acids to modify embryonic prostaglandin release needs to be examined in the context of supplementing dairy cows with different sources of fats.

On other hand, the dynamics of bovine corpus luteum regression in response to exogenous $\mathrm{PGF}_{2 \alpha}$ can also be altered by dietary fish meal. In this respect, Burke et al., (1997) fed cows 
$(n=56)$ with fish meal at either 0 or $2.8 \%$ of ration dry matter from 24 to109 days postpartum. On day 58 postpartum, all cows were injected with a luteolytic dose of $\mathrm{PGF}_{2 \alpha}$. Two days after injection of $\mathrm{PGF}_{2 \alpha}$, the proportion of cows with plasma concentrations of progesterone that were $>1 \mathrm{ng} \mathrm{ml}^{-1}$ was greater when fish meal was included in the ration than when a control ration was fed $(29.0$ vs $4 \%)$. Thus, it is possible that fatty acids present in fish oil reduce the sensitivity of the corpus luteum to $\mathrm{PGF}_{2 \mathrm{a}}$.

\section{Lipids their effect on embryo development}

Establishment of pregnancy in the ruminant requires the ovulation of a competent oocyte, of insemination at the appropriate time and of a correct pattern of secretion of oestradiol and progesterone during the follicular and luteal phase of oestrus. The embryo must develop in an appropriate way and avoid luteolysis producing enough interferon $\tau$ which stimulates the expression of genes in the endometrium to inhibit the synthesis of oxytocin receptors and consequently final production of $\mathrm{PGF}_{2 \alpha}$, allowing the establishment of a corpus luteum (Bott et al., 2010). In dairy cows there is a significant loss of embryos during this period, it is considered that only $40 \%$ of cows remain pregnant at day 28 after artificial insemination (Santos et al., 2008). There is evidence that such events can be influenced by PUFAs consumed in the ration (Wathes et al., 2007). Fatty acids play an important role in the modification of the biophysical properties and in the activity of biological membranes, including fluidity and cell proliferation (Bilby et al., 2006d). The competence and quality of the ovocyte and of the embryo are related to the type of fatty acid, specifically, with the content of particular fatty acids en the phospholipids of cell membrane which play a role in development and during and after fertilization (Santos et al., 2008).

The amount of lipids in the ovocyte of ruminants is about $76 \mathrm{ng}$ approximately and has around $58 \%$ triglycerides, $20 \%$ phospholipids, $20 \%$ cholesterol and $10 \%$ free fatty acids (McEvoy et al., 2000). Fatty acids found in greater amounts in the phospholipid fraction of the membrane of cattle ovocyte are palmitic (16:0) and oleic (18:1) acids. PUFAs represent less than $20 \%$ of the total, being linoleic acid the most abundant of them (Santos et al., 2008). Marei et al. (2010) pointed out that linoleic acid (n-6) is the most abundant fatty acid in follicular fluid of cattle and has an important role in the regulation of the process of maturation of the ovocyte, since when the cell complex of the cumulus and ovocyte were treated with linoleic acid there was a delay in the growth of the latter. Some studies have shown the fatty acid profiles in follicular fluid are affected by the estrogenic activity of the follicle (Renaville et al., 2010). Table 4 shows saturated and unsaturated fatty acids in plasma and in some reproductive tissues.

Ratio of saturated fatty acids to PUFA in granulose cells (Adamiak et al., 2005) and in the ovocyte (Wonnacott et al., 2010) is greater than in plasma. This suggests the presence of a mechanism of selective uptake in the ovarian follicles or de novo synthesis of saturated fatty acids from acetate (Wonnacott et al., 2010). Fatty acids can be oxidized as an energy source during maturation of the ovocyte and during early embryo development before implantation, in such a way that cattle ovocytes exposed to metal palmoxirate to block oxidation of fatty acids, showed a lower ability to form blastocysts after in vitro fertilization (Ferguson \& Leese, 2006). Cetica et al. (2002) reported a significant increment in the activity of the enzyme lipase during maturation of cattle ovocyte, which releases fatty acids from triglycerides for later oxidation. Apart from the role of fatty acids, particularly those saturated, as sources of energy, the content of PUFAs in the ovocyte may affect maturation, 


\begin{tabular}{|l|c|c|c|c|c|c|c|}
\hline \multicolumn{1}{|c|}{ Fatty acid group } & \multicolumn{2}{c|}{ Plasma $(\boldsymbol{\mu g} / \mathbf{m l})$} & \multicolumn{2}{c|}{$\begin{array}{c}\text { Granulosa cell } \\
(\mu \mathrm{g} / \text { pellet })\end{array}$} & \multicolumn{2}{c|}{$\begin{array}{c}\text { Oocytes } \\
\text { (ng/oocyte) }\end{array}$} \\
\hline & \multicolumn{7}{|c|}{ Dietary treatment ab } \\
\hline & $\mathrm{n}-3$ & $\mathrm{n}-6$ & $\mathrm{n}-3$ & $\mathrm{n}-6$ & $\mathrm{n}-3$ & $\mathrm{n}-6$ \\
\hline Saturated & 30.9 & 42.1 & 39.1 & 39.7 & 75.7 & 71.1 \\
\hline Unsaturated & 59.3 & 49.4 & 49.7 & 52.1 & 20.9 & 25.8 \\
\hline $\begin{array}{l}\text { Monounsaturated fatty } \\
\text { acids }\end{array}$ & 21.5 & 18.0 & 20.9 & 23.9 & 7.8 & 12.9 \\
\hline Polyunsaturated fatty acids & 37.8 & 31.4 & 28.9 & 28.2 & 13.0 & 12.9 \\
\hline n-6 PUFA & 25.4 & 28.9 & $8.5^{c}$ & 24.1 & 5.2 & 10.9 \\
\hline n-3 PUFA & $\mathbf{1 2 . 4}$ & $\mathbf{2 . 5}$ & $\mathbf{2 0 . 4}$ & $\mathbf{4 . 1}$ & $\mathbf{7 . 8}$ & $\mathbf{2 . 1}$ \\
\hline Ratio n6:n3 & $\mathbf{2 . 1}$ & $\mathbf{1 1 . 5}$ & $\mathbf{0 . 4}$ & $\mathbf{6 . 2}$ & $\mathbf{0 . 7}$ & $\mathbf{8 . 3}$ \\
\hline
\end{tabular}

Table 4. Saturated and unsaturated fatty acids in plasma and some reproductive tissues.

Adapted from Wonnacott et al. (2010) and Palmquist (2010). ${ }^{\mathrm{a}} 6.4$ \% oil in the diet supplemented from linseed oil, b5.7\% oil in the diet supplemented from sunflower oil. cImportant effects due dietary fatty acids are in bold.

cryopreservation and its capacity for further development (Wathes et al., 2007). From the n-3 fatty acids, linolenic acid has been implicated in the growth and differentiation of the ovocyte, regulation of meiotic arrest during the germinal vesicle stage and in avoiding the breaking of this structure (Kim et al., 2001).

In sheep, Zeron et al. (2002) showed that supplementation with Ca-LCFA from fish oil during 13 weeks, resulted in better quality ovocytes and better integrity of their membrane, compared to that of sheep which were not fed lipid supplements $(74.3 \%$ and $57.0 \%$, respectively), which increased the ratio of long chain fatty acids in plasma of cells from the cumulus, although these changes were not observed in the ovocytes, suggesting selective uptake by the ovocyte or a highly regulated uptake, which could limit potential impact of cow nutrition on the proportion of fatty acids in their gametes. While in beef cattle, FouladiNashta et al. (2007) fed cows with 200 or 800 g per day of Ca-LCFA from palm oil, which resulted in a greater percentage of ovum which developed up to the blastocyst stage and had a greater amount of cells due to an increment in the number of cells of the trophectoderm. By influencing the molecular mechanisms which control nucleus maturation of the ovocyte, in vitro treatment of the cumulus-oocyte complex with linolenic acid $(n-3)$, increased the percentage of gametes which reached the meiotic second division, increased the division of the embryo as well as the rate of blastocyst (Marei et al., 2009).

When a group of lactating superovulated cows were fed with rich sources of saturated fatty acids $(n-6$ or $n-3)$, rate of fertilization and the number of transferable embryos was not different; however, embryo development was increased in cows which consumed unsaturated fatty acids, compared to the cows which consumed saturated fatty acids (Thangavelu et al., 2007). Cerri et al. (2009) supplemented dairy cows with Ca-LCFA from palm oil or linoleic + octadecaenoic acids between days 25 prepartum and 80 days postpartum observing in the second group a greater proportion of excellent and good quality embryos, apart from a higher number of blastomere.

In hair ewes, Herrera et al. (2008) showed that PUFAs in the ration increased superovulatory response, registering increased $(\mathrm{P}<0.05)$ numbers of corpus luteum $(14.73 \pm 1.87$ vs $10.73 \pm 1.42)$; total cells collected, including ova plus embryos (9.18 \pm 2.16 vs $4.18 \pm 1.36)$ and 
embryos $(6.72 \pm 1.78$ vs $3.09 \pm 1.36)$ in the PUFAs treatment than in the control treatment, respectively.

On the contrary, Childs et al. (2008b) fed cows with a ration enriched with n-3 PUFAs and did not observe any effect on the number of normal embryos nor in the amount of good quality embryos (grade 1 and 2); however, these cows showed a lower number of degenerated embryos. Similarly, Bilby et al. (2006d) did not find an effect of fatty acids in the ration of dairy cows on the quality of embryos after maturation and in vitro fertilization. In a similar way, Thangavelu et al. (2007) did not establish a difference in the total number of transferable embryos of dairy cows supplemented with either PUFAs or saturated fat. Marques et al. (2007) did not observe any effect of the addition of arachidonic or eicosapentaenoic acids to the culture media for the in vitro maturation of ovocytes on the subsequent embryo development. This agrees with observations by Lawson et al. (2007) who added increasing amounts of eicosapentaenoic acid to the culture media for the maturation of ovocytes in vitro. In a recent study, Wakefield et al. (2007) suggested that contrary to the possible beneficial effects, supplementing a ration with $n-3$ PUFAs during the period just before or immediately after conception, may reduce normal development of the embryo, since this seems to disturb mitochondrial metabolism. Leroy et al. (2010) cultivated bovine zygotes in media supplemented with serum from heifers fed rations with a high content of lipids protected from rumen biohydrogenation and observed a lower production of blastocysts compared to a control treatment, noting that in the first there was a greater expression of genes related to apoptosis.

Even when in vivo and in vitro studies have shown a better embryo development with rations supplemented with lipids, results are not consistent and it is important to ascertain in particular, which fatty acids are the most beneficial for embryo survival (Santos et al., 2008). Oocytes of all mammals contain an endogenous lipid reserve. This feature reflects their common ancestral origin, the yolk-rich amniote egg. However, lipids are speciesspecific in terms of their apparent abundance and utilization. Despite the significant role of the lipid reserves in cell structure and function, very few studies have provided detailed descriptions of its nature and composition in mammalian oocytes. Table 5 gives the fatty acid composition of total lipid extracted from zone-intact oocytes of cattle and sheep.

\section{Conclusion}

Data reviewed shows that supplementation with different sources of lipids and fatty acids improve reproductive performance of the female ruminant. However, it is important to consider that the optimum response will be achieved when undernutrition status of the female is not extremely sever. A nutrient balance (protein:energy) in the ration consumed by the animal is fundamental to obtain maximum benefit from supplementation with fat, since fatty acids do not supply nitrogen for amino acid synthesis and consequently for the correct functioning of the hypothalamus-hypophysis axis. Improvements in reproductive performance may be a result of increased energy density of the ration or of the direct effects of specific fatty acids on reproductive processes. As is the case for any technology or management strategy that improves specific aspects of ovarian physiology and cyclic activity, actual improvements in pregnancy rate or total weight of calf weaned are dependent on a variety of management practices and environmental conditions. Until these interrelationships are better understood, livestock producers are recommended to attempt to formulate low cost/balanced rations. If a source of supplemental fat is available locally 


\begin{tabular}{|c|c|c|c|}
\hline \multirow[b]{2}{*}{ Name } & \multirow[b]{2}{*}{ Formula } & \multicolumn{2}{|c|}{ Mean $\left( \pm\right.$ SEM) distribution of fatty acids $(\%, w / w)^{a}$} \\
\hline & & Cattle $(n=3)^{\mathrm{b}}$ & Sheep $(n=2)$ \\
\hline Lauric & $12: 0$ & $0.23 \pm 0.15$ & nd \\
\hline Myristic & 14:0 & $2.48 \pm 1.02$ & $0.39 \pm 0.032$ \\
\hline $\begin{array}{l}\text { Palmitic } \\
\text { Palmitoleic }\end{array}$ & $\begin{array}{c}16: 0 \\
16: 1 \mathrm{n}-7\end{array}$ & $\begin{array}{l}32.0 \pm 1.64 \\
2.24 \pm 0.45\end{array}$ & $\begin{array}{l}24.7 \pm 0.74 \\
4.38 \pm 0.20\end{array}$ \\
\hline Heptadecanoic & $17: 0$ & $0.76 \pm 0.14$ & $0.41 \pm 0.407$ \\
\hline Stearic & 18:0 & $14.2 \pm 2.47$ & $16.2 \pm 0.30$ \\
\hline Oleic & $18: 1 \mathrm{n}-9$ & $25 . \pm 1.75$ & $26.2 \pm 0.23$ \\
\hline Vaccenic & $18: 1 \mathrm{n}-7$ & $3.71 \pm 0.12$ & $3.64 \pm 0.32$ \\
\hline Linoleic & $18: 2 \mathrm{n}-6$ & $5.17 \pm 0.12$ & $6.98 \pm 0.10$ \\
\hline$\gamma$-Linolenic & $18: 3 n-6$ & $0.75 \pm 0.16$ & $1.01 \pm 0.06$ \\
\hline a-Linolenic & $18: 3 n-3$ & $0.49 \pm 0.09$ & $2.01 \pm 0.41$ \\
\hline Stearidonic & $18: 4 n-3$ & nd & $1.68 \pm 0.30$ \\
\hline Arachidic & $20: 0$ & $1.35 \pm 0.70$ & $3.11 \pm 0.45$ \\
\hline Eicosenoic & $20: 1 n-9$ & $0.27 \pm 0.13$ & $0.19 \pm 0.187$ \\
\hline Eicosadienoic & $20: 2 n-6$ & $0.54 \pm 0.20$ & $0.91 \pm 0.476$ \\
\hline Eicosatrienoic & $20: 3 n-6$ & $0.27 \pm 0.15$ & $0.52 \pm 0.070$ \\
\hline Arachidonic & $20: 4 n-6$ & $1.13 \pm 0.57$ & $1.50 \pm 0.60$ \\
\hline Eicosapentaenoic & $20: 5 n-3$ & $1.15 \pm 1.15$ & $3.03 \pm 1.09$ \\
\hline Behenic & $22: 0$ & $1.23 \pm 0.63$ & $3.03 \pm 1.09$ \\
\hline Erucic & $22: 1 n-9$ & $0.20 \pm 0.10$ & nd \\
\hline Docosatetraenoic & $22: 4 n-6$ & $0.27 \pm 0.15$ & nd \\
\hline Docosapentaenoic & $22: 5 n-3$ & $0.88 \pm 0.28$ & $1.41 \pm 0.33$ \\
\hline Docosahexaenoic & $22: 6 n-3$ & $0.50 \pm 0.25$ & $1.74 \pm 0.06$ \\
\hline Lignoceric & $24: 0$ & $2.30 \pm 1.21$ & nd \\
\hline
\end{tabular}

Table 5. Fatty acid composition of total lipid extracted from zone-intact oocytes of cattle and sheep (adapted from McEvoy et al., 2000). Each sample $(n=2-4)$ represents 1000 oocytes. aPercentage $(\mathrm{w} / \mathrm{w})$ of the total fatty acids in oocyte lipid. bOne of the four original cattle oocyte samples was excluded because of uncertainty about the validity of the assay result involving cholesterol ester component of total lipid. nd: not detected.

and can be incorporated with little or no change in the cost of the ration, it would be wise for farmers to do so. Research studying the role of fat supplementation on reproductive responses has not been that consistent, therefore, adding fat to the ration would be advised when the risk of low reproductive performance (young, growing animals and limiting nutrients [protein, energy] in the basal ration) is the greatest.

\section{References}

Abayasekara, D.R.E. \& Wathes, C.D. (1999). Effects of altering dietary fatty acid composition on prostaglandin synthesis and fertility. Prostaglandins, Leukotrienes and Essential Fatty Acids, Vol.61, No.5, (November 1999), pp. 275-287. ISSN 0952-3278

Achard, D.; Gilbert, M.; Benistant, C.; Slama, S.B.; DeWitt, D.L.; Smith, W.L. \& Lagarde, M. (1997). Eicosapentaenoic and docosahexaenoic acids reduce PGH synthase 1 
expression in bovine aortic endothelial cells. Biochemical Biophysical Research Communications, Vol.241, No.2, (December 1997), pp. 513-518. ISSN 0006-291X

Adamiak, S.J.; Mackie, K.;Watt, R.G.; Webb, R. \& Sinclair, K.D. (2005). Impact of nutrition on oocyte quality: cumulative effects of body composition and diet leading to hyperinsulinemia in cattle. Biology of Reproduction, Vol.73, No.5, (November 2005), pp. 918-926. ISSN 0006-3363

Aguilar-Pérez, C.; Ku-Vera, J. \& Garnsworthy C.P. (2009). Effects of bypass fat on energy balance, milk production and reproduction in grazing crossbred cows in the tropics. Livestock Science, Vol.121, No.1, (March 2009), pp64-71. ISSN: 1871-1413

Ambrose, D.J.; Estill, C.T.; Colazo, M.G.; Kastelic, J.P. \& Corbett, R. (2006b). Conception rates and pregnancy losses in dairy cows fed a diet supplemented with rolled flaxseed. Proceedings of the $7^{\text {th }}$ International Ruminant Reproduction Symposium, Wellington, New Zealand. Abstract 50.

Ambrose, D.K.; Kastelic, J.P.; Corbett, R.; Pitney, P.A.; Petit, H.V.; Small, J.A. \& Zalkovic, P. (2006a). Lower pregnancy losses in lactating dairy cows fed a diet enriched in alinolenic acid. Journal of Dairy Science, Vol.89, No.8, (August 2006), pp. 3066-3074. ISSN 1811-9751

Aranda-Ávila, I.; Herrera-Camacho J.; Aké-López J. R.; Delgado-León R.A. \& Ku-Vera, J. C. (2010). Effect of supplementation with corn oil on postpartum ovarian activity, pregnancy rate, and serum concentration of progesterone and lipid metabolites in F1 (Bos taurus $\times$ Bos indicus) cows. Tropical Animal Health and Production, Vol.42, No.7 (October 2010), pp. 1435-1440. ISSN 1573-7438

Armstrong, J.D.; Goodall, E.A.; Gordon, F.J.; Rice, D.A. \& McCaughey, W.J. (1990). The effects of levels of concentrate offered and inclusion of maize gluten or fish meal in the concentrate on reproductive performance and blood parameter of dairy cows. Animal Production, Vol.50, No.1, (September, 1990), pp. 1-10. ISSN 1357-7298

Bader, J.F.; Felton, E.E.D.; Kerley, M.S.; Simms, D.D. \& Patterson, D.J. (2000). Effects of postpartum fat supplementation on reproduction in primiparous 2-year-old and mature cows. Journal of Animal Science, Vol.78, Suppl. No.1, (July 2000), pp. 224. ISSN 1525-3163. Journal of Dairy Science, Vol.83, Suppl. No.1, (July 2000), pp. 224. ISSN 0022-0302

Bernal SG.; O'Donnell, A. M.; Vicini, J. L.; Hartnell, G. F. \& Bauman, D. E. (2010). Enhancing omega-3 fatty acids in milk fat of dairy cows by using stearidonic acid-enriched soybean oil from genetically modified soybeans. Journal of Dairy Science, Vol.93, No.1, (January 2010), pp. 32-37. ISSN 0022-0302

Bernal-Santos, G.; Perfield II, J.W.; Barbano, D. M.; Bauman, D.E. \& Overton, T.R. (2003). Production responses of dairy cows to dietary supplementation with conjugated linoleic acid (CLA) during the transition period and early lactation. Journal of Dairy Science, Vol.86, No. 10, (October 2003), pp. 3218-3228. ISSN 0022-0302

Bilby, T.R.; Block, J.; do Amaral, B.C.; Sa Filho, O.; Silvestre, F.T.; Hansen, P.J.; Staples, C.R. \& Thatcher, W.W. (2006d). Effects of dietary unsaturated fatty acids on oocyte quality and follicular development in lactating dairy cows in summer. Journal of Dairy Science, Vol.89, No.10 (October 2006), pp. 3891-3903. ISSN 0022-0302 
Bilby, T.R.; Guzeloglu, A., MacLaren, L.A., Staples, C.R., Thatcher, W.W. (2006a). Pregnancy, bST and omega-3 fatty acids in lactating dairy cows: II. Gene expression related to maintenance of pregnancy. Journal of Dairy Science, Vol.89, No.9 (September 2006), pp. 3375-3385. ISSN 0022-0302

Bilby, T.R., Jenkins, T.; Staples, T.R. \& Thatcher, W.W. (2006b). Pregnancy, bovine somatotropin, and dietary $n-3$ fatty acids in lactating dairy cows: III. Fatty acid distribution. Journal of Dairy Science, Vol.89, No.9, (September 2006), pp. 3386-3399. ISSN 0022-0302

Bilby, T.R.; Sozzi, A.; Lopez, M.M.; Silvestre, F.T.; Ealy, A.D.; Staples, C.R. \& Thatcher, W.W. (2006c). Pregnancy, bovine somatotropin, and dietary $n-3$ fatty acids in lactating dairy cows: I. ovarian, conceptus, and growth hormone-insulin-like growth factor system responses. Journal of Dairy Science, Vol.89, No.9 (September 2006), pp. 33603374. ISSN 0022-0302

Binelli, M., Thatcher, W.W., Mattos, R., Baruselli, P.S. (2001). Antiluteolytic strategies to improve fertility in cattle. Theriogenology, Vol.56, No.9 (December 2001), pp. 145163. ISSN: 0093-691X

Bott, R.C.; Ashley, R.L.; Henkes, L.E.; Antoniazzi, A.Q.; Bruemmer, J.E.; Niswender, G.D.; Bazer, F.W.; Spencer, T.E.; Smirnova, N.P.; Anthony, R.V. \& Hansen, T.R. (2010). Uterine vein infusion of interferon Tau (IFNT) extends luteal life span in ewes. Biology of Reproduction, Vol.82, No.4 (April 2010), pp. 725-735. ISSN 0006-3363

Bruckental, I.; Dori, D.; Kaim, M.; Lehrer. H. \& Folman, Y. (1989). Effects of source and level of protein on milk yield and reproductive performance of high-producing primiparous and multiparous dairy cows. Animal Production, Vol.48, No.2 (April 1989), pp. 319-329. ISSN 1357-7298

Burke, J.M.; Staples, C.R.; Risco, C.A.; De La Sota, R.L. \& Thatcher, W.W. (1997). Effect of ruminant grade menhaden fish meal on reproductive and productive performance of lactating dairy cows. Journal of Dairy Science, Vol.80, No.12 (December 1997), pp. 3386-3398. ISSN 0022-0302

Burns, P.D., Engle, T.E., Harris, M.A., Enns, R.M., Whittier, J.C. (2003). Effect of fish meal supplementation on plasma and endometrial fatty acid composition in nonlactating beef cows. Journal of Animal Science, Vol.81, No.11 (November 2003), pp. 2840-2846. ISSN 1525-3163

Burr, G.O. \& Burr, M.M. (1930). On the nature and role of the fatty acids essential in nutrition. Journal of Biological Chemistry, Vol.86, No.2 (April 1930), pp. 587-621. ISSN 0021-9258

Caldari-Torres, C.; Rodriguez-Sallaberry, C.; Greene, E.S. \& Badinga, L. (2006). Differential effects of $n-3$ and $n-6$ fatty acids on prostaglandin $F_{2 a}$ production by bovine endometrial cells. Journal of Dairy Science, Vol.89, No.3 (March 2006), pp 971-977. ISSN 0022-0302

Carroll, D.J.; Hossain, F.R. \& Keller, M.R. (1994). Effect of supplemental fish meal on the lactation and reproductive performance of dairy cows. Journal of Dairy Science, Vol.77, No.10 (Octiber 1994), pp. 3058-3072. ISSN 0022-0302

Castañeda-Gutierrez, E.; Overton, T.R.; Butler, W.R. \& Bauman, D.E. (2005). Dietary supplements of two doses of calcium salts of conjugated linoleic acid during the 
transition period and early lactation. Journal of Dairy Science, Vol.88, No.3 (March 2005), pp. 1078-1089. ISSN 0022-0302

Castellano CA, Audet, I. Bailey, J. L., Chouinard, P. Y., Laforest, J.P., Matte, J. J. (2010). Effect of dietary n-3 fatty acids (fish oils) on boar reproduction and semen quality. Journal of Animal Science, Vol.88, No7 (July 2010), pp. 2346-2355. ISSN 1525-3163

Cerri, R.L.A.; Juchem, S.O.; Chebel, R.C.; Rutgliano, H.; Bruno, R.G.S.; Galvaõ, K.N.; Thatcher, W.W. \& Santos, J.E. (2009). Effect of fat source differing in fatty acid profile on metabolic parameters, fertilization, and embryo quality in highproducing dairy cows. Journal of Dairy Science, Vol.92, No.4 (April 2009), pp. 15201531. ISSN 0022-0302

Cetica, P.; Pintos, L.; Dalvit, G. \& Beconi, M. (2002). Activity of key enzymes involved in glucose and triglyceride catabolism during bovine oocyte maturation in vitro. Reproduction, Vol.124, No5 (November 2002), pp. 675-681. ISSN 1741-7899

Childs, S.; Carter, F.; Lynch, C.O.; Sreenan, J.M.; Lonergan, P.; Hennessy, A.A. \& Kenny, D.A. (2008b). Embryo yield and quality following dietary supplementation of beef heifers with n-3 polyunsaturated fatty acids (PUFA). Theriogenology, Vol.70, No.6 (October 2008), pp. 992-1003. ISSN 0093-691X

Childs, S.; Hennessy, A.A.; Sreenan, J.M.; Wathes, C.; Cheng, Z.; Stanton, C.; Diskin, M.G. \& Kenny, D.A. (2008a). Effect of level of dietary n-3 polyunsaturated fatty acid supplementation on systemic and tissue fatty acid concentrations and on selected reproductive variables in cattle. Theriogenology, Vol.70, No.4 (September 2008), pp. 595-611. ISSN 0093-691X

Childs, S.; Lynch, C.O.; Hennessy, A.A.; Stanton, C.; Wathes, D.C.; Sreenan, J.M.; Diskin, M.G. \& Kenny, D.A. (2008c). Effect of dietary enrichment with either $n-3$ or $n-6$ fatty acids on systemic metabolite and hormone concentration and ovarian function in heifers. Animal, Vol.2, No.6 (May 2008), pp. 883-893. ISSN 1751-7311

Coyne, G.S.; Kenny, D.A.; Childs, S.S.; Sreenan, J.M. \& Waters, S.M. (2008). Dietary n-3 polyunsaturated fatty acids alter the expression of genes involved in prostaglandin biosynthesis in the bovine uterus. Theriogenology, Vol.70, No.5 (September 2008), pp. 772-782. ISSN 0093-691X

Cullens, F.M. (2005). Effects of the timing of initiation of fat supplementation on productive and reproductive responses of periparturient dairy cows during summer. MSc. Thesis. University of Florida, USA. Pp.146.

de Fries, C.A., Neuendorff, D.A., Randel, R.D. (1998). Fat supplementation influences postpartum reproductive performance in Brahman cows. Journal of Animal Science, Vol.76, No.3 (March 1998), pp. 864-870. ISSN 1525-3163

de Luna, C.J., Brown, W.H., Ray, D.E., Wegner, T.N. (1982). Effects of protected fat supplement on GnRH induced LH release in ovariectomized and early postpartum beef cow. Journal of Animal Science, Vol.55, No.Suppl. 1, pp. 348 (Abstr) ISSN 15253163

de Veth, M.J.; Bauman, D.E.; Koch, W.; Mann, G.E.; Pfeiffer, A.M. \& Butler, W.R. (2009). Efficacy of conjugated linoleic acid for improving reproduction: A multi-study analysis in early-lactation dairy cows. Journal of Dairy Science, Vol.92, No.6 (June 2009), pp. 2662-2669. ISSN 0022-0302 
Doreau, M.; Bauchart, D. \& Chilliard, Y. (2011). Enhancing fatty acid composition of milk and meat through animal feeding. Animal Production Science, Vol.51, No.1 (December 2010), pp. 19-29. ISSN 1836-0939

El-Shahat, K.H. \& Abo-El maaty, A.M. (2010). The effect of dietary supplementation with calcium salts of long chain fatty acids and/or l-carnitine on ovarian activity of Rahmani ewes. Animal Reproduction Science, Vol.117, No.1-2 (January 2010), pp. 7882. ISSN: 0378-4320

Espinoza, J.L.; Ramírez-Godínez, J.A.; Jiménez, J.A. \& Flores, A. (1995). Effects of calcium soaps of fatty acids on postpartum reproductive activity in beef cows and growth of calves. Journal of Animal Science, Vol.73, No.10 (October 1995), pp. 2888-2892. ISSN 1525-3163

Espinoza, J.L.; Ramirez-Godinez, J.A.; Simental, S.S.; Jiménez, J.; Ramirez, R.; Palacios, A., \& de Luna, R. (1997). Effects of calcium soaps of fatty acids on serum hormones and lipid metabolites in Pelibuey ewes. Small Ruminant Research, Vol.26, No.1 (December 1997), pp. 61-68. ISSN: 0921-4488

Espinoza-Villavicencio, J.L.; Ortega-Pérez, R.; Palacios-Espinosa, A. \& Guillén-Trujillo, A. (2010). Efecto de la suplementación de grasas sobre características productivas, tasas de preñez y algunos metabolitos de los lípidos en vacas para carne en pastoreo. Archivos de Medicina Veterinaria, Vol.42, No.1 (Enero 2010); pp. 25-32. ISSN 0301-732X

Ferguson, E.M. \& Leese, H.J. (2006). A potential role for triglyceride as an energy source during bovine oocyte maturation and early embryo development. Molecular Reproduction and Development, Vol.73, No.9 (September 2006), pp. 1195-1201. ISSN 1040-452X

Ferguson, J.D.; Sklan, D.; Chalupa, W.V. \& Kronfeld, D.S. (1990). Effects of hard fat on in vitro and in vivo rumen fermentation, milk production, and reproduction in dairy cows. Journal of Dairy Science; Vol.73, No.10 (October 1990), pp. 2864-2879. ISSN 0022-0302

Filley, S.J; Turner, H.A. \& Stormshak F. (2000). Plasma fatty acids, prostaglandin F2a metabolite, and reproductive response in postpartum heifers fed rumen bypass fat. Journal of Animal Science, Vol.78, No.1 (January 2000), pp. 139-144. ISSN 1525-3163

Fouladi-Nashta, A.A.; Gutierrez, C.G.; Gong, J.G.; Garnsworthy, P.C. \& Webb, R. (2007). Impact of dietary fatty acids on oocyte quality and development in lactating dairy cows. Biology of Reproduction, Vol.77, No. 1 (July 2007), pp. 9-17. ISSN: 0006-3363

Fuentes, M.C.; Calsamiglia, S.S.; Sánchez, C.; González, A.; Newbold, J.; Santos, J.E.P.; Rodríguez-Alcalá, L.M. \& Fontecha, J. (2008). Effect of extruded linseed on productive and reproductive performance of lactating dairy cows. Livestock Science, Vol.113, No.2 (February 2008), pp. 144-154. ISSN: 1871-1413

Funston, R. \& Filley, S. (2002). Effects of fat supplementation on reproduction in beef cattle. Proceedings of The Applied Reproductive Strategies in Beef Cattle Workshop, September 5-6, 2002, Manhattan, Kansas. USA. 1-8 p.

Funston, R.N. (2004). Fat supplementation and reproduction in beef females. Journal of Animal Science, Vol.82, No.13 (January 2004), pp. 154-161. E suppl. ISSN 1525-3163 
Garcia-Bojalil, C.M.; Staples, C.R.; Risco, C.A.; Savio, J.D. \& Thatcher, W.W. (1998). Protein degradability and calcium salts of long chain fatty acids in the diets of lactating dairy cows: productive responses. Journal of Dairy Science, Vol.81, No. 5 (May 1998), pp. 1374-1384. ISSN 0022-0302

Garnsworthy, P.C.; Lock, A.; Mann, G.E.; Sinclair, K.D. \& Webb, R. (2008). Nutrition, metabolism, and fertility in dairy cows: 2. Dietary fatty acids and ovarian function. Journal of Dairy Science, Vol.91, No. 10 (October 2008), pp. 3824-3833. ISSN 00220302

Gray, C.A.; Taylor, K.M.; Ramsey, W.S.; Hill, J.R.; Bazer, F.W.; Bartol, F.F. \& Spencer, T.E. (2001). Endometrial glands are required for preimplantation conceptus elongation and survival. Biology of Reproduction Vol.64, No.6 (June 2001), pp. 1608-1613. ISSN 0006-3363

Harris, M.A.; Hansen, R.A.; Vidsudhiphan, P.; Koslo, J.L.; Thomas, J.B.; Watkins, B.A. \& Allen, K.G. (2001). Effects of conjugated linoleic acids and docosahexaenoic acid on rat liver and reproductive tissue fatty acids, prostaglandins and matrix metalloproteinase production. Prostaglandins Leukotrienes and Essential Fatty Acids, Vol.65, No.1 (July 2001), pp. 23-29. ISSN 0952-3278

Harrison J.H.; Kincaid, R.L.; McNamara, J.P.; Waltner, S.; Loney, K.A.; Riley, R.E. \& Cronrath, J.D. (1995). Effect of whole cottonseeds and calcium salts of long-chain fatty acids on performance of lactating dairy cows. Journal of Dairy Science, Vol.78, No.1 (January 1995), pp. 181-193. ISSN 0022-0302

Heravi-Moussavi, A.R.; Gilbert, R.O.; Overton, T.R.; Bauman, D.E. \& Butler, W.R. (2007). Effect of feeding fish meal and $n-3$ fatty acids on ovarian and uterine responses in early lactating dairy cows. Journal of Dairy Science, Vol.90, No.1 (January 2007), pp. 145-154. ISSN 0022-0302

Herrera-Camacho, J.; Aké-López, J.R.; Ku-Vera, J.C.; Williams, G.L. \& Quintal-Franco, J.A. (2008). Respuesta ovulatoria, estado de desarrollo y calidad de embriones de ovejas Pelibuey superovuladas suplementadas con ácidos grasos poliinsaturados. Tecnica Pecuaria en Mexico, Vol.46, No.2 (Abril-Junio 2008), pp. 107-117. ISSN 0040-1889

Hightshoe, R.B., Cochran, R.C., Corah, L.R., Kiracofe, G.H., Harmon, D.L., Perry, R.C. (1991). Effects of calcium soaps of fatty acids on postpartum reproductive function in beef cows. Journal of Animal Science, Vol.69, No.10 (October 1991), pp. 4097-4103. ISSN 1525-3163

Hinckley, T., Clark, R.M., Bushmich, S.L. Milvae, R.A. (1996). Long chain polyunsaturated fatty acids and bovine luteal cell function. Biology of Reproduction, Vol.55, No.2 (August 1996), pp. 445-449. ISSN 0006-3363

Howard, J.J., Scott, R.G., Britt, J.H. (1990). Associations among progesterone, estradiol-17b, and prostaglandin in cattle treated with hCG during diestrus to extend corpus luteum function. Prostaglandins, Vol.40, No.1 (July 1990), pp. 51-70. ISSN1098-8823

Huante CR. (2010). Efecto de la suplementación de dos tipos de ácidos grasos sobre el reinicio de la actividad ovárica y metabolitos de lípidos en vacas F1 (Bos taurus $x$ Bos indicus) durante el posparto temprano. Maestria Institucional en Ciencias Biológicas. Instituto de Investigaciones Agropecuarias y Forestales. Universidad Michoacana de San Nicolás de Hidalgo. Morelia, Michoacán, México. 
Juchem, S.O. (2007). Lipid Digestion and Metabolism in Dairy Cows: Effects on Production, Reproduction and Health. PhD thesis, University of California Davis, USA.

Juchem, S.O.; Cerri, R.L.A.; Bruno, R.; Galvao, K.N.; Lemos, E.W.; Villasenor, M.; Coscioni, A.C.; Rutgliano, H.M.; Thatcher, W.W.; Luchini, D. \& Santos, J.E.P. (2004). Effect of feeding Ca salts of palm oil (PO) or a blend of linoleic and monoenoic trans fatty acids (LTFA) on uterine involution and reproductive performance in Holstein cows. Journal of Animal Science, Vol.82 / Journal of Dairy Science, Vol.87 / Poultry Science, Vol.83, Suppl.1 pp. 310 (Abstract 633). ISSN 1525-3163 / ISSN 0022-0302 / ISSN: 0032-5791

Juchem, S.O.; Cerri, R.L.A.; Villaseñor, M.; Galvão, K.N.; Bruno, R.G.S.; Rutigliano, H.M.; DePeters, E.J.; Silvestre, F.T.; Thatcher, W.W. \& Santos, J.E.P. (2010). Supplementation with calcium salts of linoleic and trans-octadecenoic acids improves fertility of lactating dairy cows. Reproduction in Domestic Animals, Vol.45, No.1 (February 2010), pp. 55-62. ISSN 1439-0531

Kim, J.Y.; Kinoshita, M.; Ohnishi, M. \& Fukui, Y. (2001). Lipid and fatty acid analysis of fresh and frozen-thawed immature and in vitro matured bovine oocytes. Reproduction, Vol.122, No.1 (July 2001), pp. 131-138. ISSN 1470-1626.

Knickerbocker, J.J.; Thatcher, W.W.; Foster, D.B.; Wolfenson, D.; Bartol, F.F. \& Caton, D. (1986). Uterine prostaglandin and blood flow responses to estradiol-17 $\beta$ in cyclic cattle. Prostaglandins, Vol.31, No.4 (April 1986), pp. 757-776. ISSN1098-8823

Lammoglia, M. A.; Willard, S. T.; Oldham, J. R. \& Randel, R. D. (1996). Effects of dietary fat and season on steroid hormonal profiles before parturition and on hormonal, cholesterol, triglycerides, follicular patterns and postpartum reproduction in Brahman cows. Journal of Animal Science, Vol.74, No.9 (September 1996), pp. 22532262. ISSN 1525-3163

Lawson, C.; Wade, M.; Kenny, D.A. \& Lonergan, P. (2007). Effect of addition of eicosapentaenoic acid (EPA) to culture medium on development of bovine embryos in vitro. In: Annual Meeting of the European Embryo Transfer Association. 190 p.

Lemley, C.O.; Butler, S.T.; Butler, W.R. \& Wilson, M.E. (2008). Short communication: Insulin alters hepatic progesterone catabolic enzymes cytochrome P450 2C and 3A in dairy cows. Journal of Dairy Science, Vol.91, No.2 (February 2008), pp. 641-645. ISSN 00220302

Leroy, J.L.; Van Hoeck, V.; Clemente, M.; Rizoz, D.; Gutierrez-Adan, A.; Van Soom, A.; Uytterhoeven, M. \& Bols, P.E. (2010). The effect of nutritionally induced hyperlipidemia on in vitro bovine embryo quality. Human Reproduction, Vol.25, No.3 (March 2010), pp. 768-778. ISSN 0268-1161

Lopes, N.; Scarpa, A.B.; Cappellozza, B.I.; Cooke, R.F. \& Vasconcelos, J.L.M. (2009). Effects of rumen-protected polyunsaturated fatty acid supplementation on reproductive performance of Bos indicus beef cows. Journal of Animal Science, Vol.87, No.12 (December 2009), pp. 3935-3943. ISSN 1525-3163

Lucy, M.C.; De La Sota, R.L.; Staples, C.R. \& Thatcher, W.W. (1993). Ovarian follicular populations in lactating dairy cows treated with recombinant bovine somatotropin (sometribove) or saline and fed diets differing in fat content and energy. Journal of Dairy Science; Vol.76, No.4 (April 1993), pp. 1014-1027. ISSN 0022-0302 
Lucy, M.C.; Staples, C.R.; Michel, F.M. \& Thatcher, W.W. (1991). Effect of feeding calcium soaps to early postpartum dairy cows on plasma prostaglandin F2a, Luteinizing hormone, and follicular growth. Journal of Dairy Science, Vol.74, No.2 (February 1991), pp. 483-489. ISSN 0022-0302

Lucy, M.C.; Thatcher, W.W.; Michel, F.J. \& Staples, C.R. (1989). Effect of dietary calcium soaps of long chain fatty acids (Megalac) on plasma prostaglandin F metabolite (PGFM), LH, energy balance and follicular population in early postpartum dairy cattle. Journal of Animal Science, Vol.67, No. Suppl. 1389 (Abstr). ISSN 1525-3163

Marei, F.W.; Wathes, D.C. \& Fouladi-Nashta, A.A. (2010). Impact of linoleic acid on bovine oocyte maturation and embryo development. Reproduction, Vol.139, No.6 (June 2010), pp. 979-988. ISSN 1470-1626

Marei, W.F.; Wathes, D.C. \& Fouladi-Nashta, A.A. (2009). The effect of linolenic acid on bovine oocyte maturation and development. Biology of Reproduction, Vol.81, No.6 (December 2009), pp. 1064-1072. ISSN 0006-3363

Marín-Aguilar, M.A.; Tinoco-Magaña, J.C.; Herrera-Camacho, J.; Sánchez-Gil, L.G.; SánchezParra, V.M.; Solorio-Rivera, J.L. \& García-Valladares, A. (2007). Reinicio de la actividad ovárica y nivel de metabolitos de lípidos en vacas lecheras suplementadas con aceite vegetal durante el posparto temprano. Interciencia, Vol.32, No.3, (March 21007), pp. 180-184. ISSN 0378-1844

Marques, C.C.; Baptista, M.C.; Vasques, M.I.; Horta, A.E.M. \& Pereira, R.M. (2007). Effect of polyunsaturated fatty acids (PUFA) on bovine oocyte in vitro maturation and subsequent embryo development and freezability. Reproduction in Domestic Animals, Vol.109, No.Suppl. 2 (September 2007), pp. 116. ISSN: 0936-6768

Mattos, R.; Guzeloglu, A.; Badinga, L.; Staples, C.R. \& Thatcher, W.W. (2003). Polyunsaturated fatty acids and bovine interferon-s modify phorbol ester-induced secretion of prostaglandin F2 $\alpha$ and expression of prostaglandin endoperoxide synthase-2 and phospholipase-A2 in bovine endometrial cells. Biology of Reproduction, Vol.69, No.3 (September 2003), pp. 780-787. ISSN 0006-3363

Mattos, R.; Staples, C.R.; Arteche, A.; Wiltbank, M.C.; Diaz, F.J.; Jenkins, T.C. \& Thatcher, W.W. (2004). The effects of feeding fish oil on uterine secretion of PGF2 $\alpha$, milk composition, and metabolic status of periparturient Holstein cows. Journal of Dairy Science, Vol.87, No.4 (April 2004), pp. 921-932. ISSN 0022-0302

Mattos, R.; Staples, C.R. \& Thatcher, W.W. (2000). Effects of dietary fatty acids on reproduction in ruminants. Reviews of Reproduction, Vol.5, No.1 (January 2000), pp. 38-45. ISSN 1470-1626

McEvoy, T.G.; Coull, G.D.; Broadbent, P.J.; Hutchinson, J.S.M. \& Speake, B.K. (2000). Fatty acid composition of lipids in immature cattle, pig and sheep oocytes with intact zona pellucida. Journal of Reproduction and Fertility, Vol.118, No.1 (January 2000), pp. 163-170. ISSN 0022-4251

McNamara, S.; Butler, T.; Ryan, D.P.; Mee, J.F.; Dillon, P.; O'Mara, F.P.; Butler, S.T.; Anglese, D.; Rath, M. \& Murphy, J.J. (2003). Effect of offering rumen-protected fat supplements on fertility and performance in spring-calving Holstein-Friesian cows. Animal Reproduction Science, Vol.79, No.1-2; (November 2003); pp. 45-56. ISSN 03784320 
Meier, S.; Ledgard, A.M.; Sato, T.A.; Peterson, A.J. \& Mitchell, M.D. (2009). Polyunsaturated fatty acids differentially alter PGF2 $\alpha$ and $\mathrm{PGE}_{2}$ release from bovine trophoblast and endometrial tissues during short-term culture. Animal Reproduction Science, Vol.111, No.2-4 (April 2009), pp. 353-360. ISSN 0378-4320

Oldick, B.S.; Staples, C.R.; Thatcher, W.W. \& Gyawu, P. (1997). Abomasal infusion of glucose and fat-effect on digestion, production, and ovarian and uterine function of cows. Journal of Dairy Science, Vol.80, No.7 (July 1997), pp. 1315-1328. ISSN 00220302

Palmquist, D.L. (2010). Essential fatty acids in ruminant diets. Proceedings of the 21 nd Annual Ruminant Nutrition Symposium, February 2-3, 2010. Gainesville, Florida, USA. pp. 127-141

Piccinato, C.A.; Sartori, R.; Sangsritavong, S.; Souza, A.H.; Grummer, R.R.; Luchini, D. \& Wiltbank, M.C. (2010). In vitro and in vivo analysis of fatty acid effects on metabolism of $17 \beta$-estradiol and progesterone in dairy cows. Journal of Dairy Science, Vol.93, No.5 (May 2010), pp. 1934-1943. ISSN 0022-0302

Rego, A.O.; Portugal, V.P.; Sousa B.M.; Rosa H.J.D.; Vozuela M.C.; Borba E.S.A. \& Bessa R.J.B. (2004). Effect of diet on the fatty acid pattern of milk from dairy cows. Animal Research, Vol.53, No.3 (May-June 2004), pp. 213-220. ISSN 1627-3591

Renaville, B.; Bacciu, N.; Comin, A.; Motta, M.; Poli, I.; Vanini, G.; Prandi, A. (2010). Plasma and follicular fluid fatty acid profiles in dairy cows. Reproduction in Domestic Animals, Vol.45, No.1 (February 2010), pp. 118-121. ISSN 0936-6768

Robinson, R.S., Pushpakumara, P.G.A., Cheng, Z., Peters, A.R., Abayasekara, D-E-E., Wathes, D.C. (2002). Effects of dietary polyunsaturated fatty acids on ovarian and uterine function in lactating dairy cows. Reproduction, Vol.124, No.1 (July 2002); pp. 119-131. ISSN 1470-1626

Ryan, D. P.; Spoon, R.A.; Griffith, M.K. \& Williams, G.L. (1994). Ovarian follicular recruitment, granulosa cell steroidogenic potential, and growth hormone/insulinlike growth factor-1 relationships in beef cows consuming high lipid diets: Effects of graded differences in body condition maintained during the puerperium. Domestic Animal Endocrinology, Vol.11, No.2 (April 1994), pp. 161-174. ISSN 07397240

Ryan, D.P.; Bao, B.; Griffith, M.K. \& Williams, G.L. (1995). Metabolic and luteal sequelae to heightened dietary fat intake in postpartum beef cows. Journal of Animal Science, Vol.73, No.7 (July 1995), pp. 2086-2093. ISSN 1525-3163

Ryan, D.P.; Spoon, R.A. \& Williams, G.L. (1992). Ovarian follicular characteristics, embryo recovery, and embryo viability in heifers fed high fat diets and treated with folliclestimulating hormone. Journal of Animal Science, Vol.70, No.11 (November 1992); p. 3505-3513. ISSN 1525-3163

Salas-Razo, G.; Herrera-Camacho, J.; Gutiérrez-Vázquez, E.; Ku-Vera, J.C. \& Aké-López J.R. (2011). Postpartum ovarian activity resumption and plasma concentration of lipid metabolites and progesterone in Indobrasil cows in the dry tropics of Michoacan supplemented with bypass fat. Tropical and Subtropical Agroecosystems (in press). ISSN 1870-0462 
Santos, J.E.P.; Bilby, T.R.; Thatcher, W.W.; Staples, C.R. \& Silvestre, F.T. (2008). Long chain fatty acids of diet as factors influencing reproduction in cattle. Reproduction in Domestic Animals, Vol.43, No. Suppl. 2 (July 2008), pp. 23-30. ISSN 1627-3591

Scott, T.A.; Shaver, R.D.; Zepeda, L.; Yandell, B. \& Smith, T.R. (1995). Effects of rumen-inert fat on lactation, reproduction, and health of high producing Holstein herds. Journal of Dairy Science, Vol.78, No.11 (Novembre 1995), pp. 2435-2451. ISSN 0022-0302

Sklan, D.; Kaim, M.; Moallem, U. \& Folman, Y. (1994). Effect of dietary calcium soaps on milk yield, body weight, reproductive hormones, and fertility in first parity and older cows. Journal of Dairy Science, Vol.77, No.6 (June 1994), pp. 1652-1660. ISSN 0022-0302

Sklan, D.; Moallem, U. \& Folman, Y. (1991). Effect of feeding calcium soaps of fatty acids on production and reproductive responses in high producing lactating cows. Journal of Dairy Science, Vol.74, No.2 (February 1991), pp. 510-517. ISSN 0022-0302

Smith, S.S.; Neuringer, M. \& Ojeda, S.R. (1989). Essential fatty acid deficiency delays the onset of puberty in the female rat. Endocrinology, 125:1650-1659. ISSN: 0013-7227.

Son, J.; Grant, R.J. \& Larson, L.L. (1996). Effects of tallow and escape protein on lactational and reproductive performance of dairy cows. Journal of Dairy Science, Vol.79, No.5 (May 1996), pp. 822-830. ISSN 0022-0302

Sreenan, J.M.; Diskin, M.G. \& Morris, D.G. (2001). Embryo survival rate in cattle: a major limitation to the achievement of high fertility. In: Fertility in the high producing dairy cow. BSAS Occasional Publication, Vol.1, pp. 93-105.

Stanko, R. L.; Fajersson, P.; Carver, L.A. \& Williams, G.L. (1997). Follicular growth and metabolic changes in beef heifers fed incremental amounts of polyunsaturated fat. Journal of Animal Science, Vol.75, No. Suppl. 1 (July-August 1997), pp. 223 (Abstr 376). ISSN 1525-3163

Staples, C.R.; Burke, J.M. \& Thatcher, W.W. (1998). Influence of supplemental fats on reproductive tissues and performance of lactating cows. Journal of Dairy Science, Vol.81, No.3 (March 1998), pp. 856-871. ISSN 0022-0302

Staples, C.R., Thatcher, W.W. (2005). Effects of fatty acids on reproduction of dairy cows. In: Garnsworthy PC, Wiseman, J. (Eds.), Recent Advances in Animal Nutrition. Nottingham University Press, Nottingham, UK, 229-256 p.

Stocco, D.M.; Wang, X.; Jo, Y. \& Manna, P.R. (2005). Multiple signaling pathways regulating steroidogenesis and steroidogenic acute regulatory protein expression: more complicated than we thought. Molecular Endocrinology, Vol.19, No.11 (November 2005), pp. 2647-2659. ISSN 0888-8809

Talavera, F.; Park, C. S. \& Williams, G. L. (1985). Relationships among dietary lipid intake, serum cholesterol and ovarian function in Holstein heifers. Journal of Animal Science, Vol.60, No.4 (April 1985); pp. 1045-1051. ISSN 1525-3163

Thangavelu, G.; Colazo, M.G.; Ambrose, D.J.; Oba, M.; Okine, E.K. \& Dyck, M.K. (2007). Diets enriched in unsaturated fatty acids enhance early embryonic development in lactating Holstein cows. Theriogenology 68:949-957. ISSN 0093-691X

Thatcher, W.W.; Macmillan, K.L.; Hansen, P.J. \& Bazer, F.W. (1994). Embryonic losses: causes and prevention. In: Fields, M.J.S., Sand, R.S. Editors. Factors affecting calf crop. Boca Raton, FL: CRC Press; 135-153 p. 
Thatcher, W.W. \& Staples, C.R. (2000). Effects of dietary fat supplementation on reproduction in lactating dairy cows. Advanced in Dairy Technology, Vol.12, No.12 (December 2000), pp. 213-232. ISSN 1184-0684.

Thatcher, W.W. \& Staples, R.C. (2007). Using fats and fatty acids to enhance reproductive performance. Proceedings of the $5^{\text {th }}$ Mid-Atlantic Nutrition Conference.. 115 Zimmermann, N.G., ed., University of Maryland, College Park, MD 20742. USA. 116-129 p.

Thomas, M.G. \& Williams, G.L. (1996). Metabolic hormone secretion and FSH-induced superovulatory responses of beef heifers fed dietary fat supplements containing predominantly saturated or polyunsaturated fatty acids. Theriogenology, Vol.45 (January), pp. 451-458. ISSN 0093-691X

Thomas, M.G.; Bao, B. \& Williams, G.L. (1997). Dietary fats varying in their fatty acid composition differentially influence follicular growth in cows fed isoenergetic diets. Journal of Animal Science, Vol.75, No.9 (September 1997), pp. 2512-2519. ISSN 15253163

Wakefield, S.L.; Lane, M.; Schulz, S.J.; Hebart, M.L.; Thompson, J.G. \& Mitchell, M. (2007). Maternal supply of omega 3 polyunsaturated fatty acids alter mechanisms envolved in oocyte and early embryo development in the mouse. American Journal of Physiology, Endocrinology and Metabolism, Vol.294, No.2 (February 2008); pp. E425E434. ISSN 0193-1849.

Wang, C.K.; Robinson, R.S.; Flint, A.P. \& Mann, G.E. (2007). Quantitative analysis of changes in endometrial gland morphology during the bovine oestrous cycle and their association with progesterone levels. Reproduction, Vol.134, No.2 (August 2007); pp. 365-371. ISSN 1470-1626

Wathes, D.C.; Abayasekara, D.R. \& Aitken, R.J. (2007). Polyunsaturated fatty acids in male and female reproduction. Biology of Reproduction, Vol.77, No.2 (August 2007), pp. 190-201. ISSN 0006-3363

Wehrman, M. E.; Welsh, T.H.Jr. \& Williams, G.L. (1991). Diet-induced hyperlipidemia in cattle modifies the intrafollicular cholesterol environment, modulates ovarian follicular dynamics, and hastens the onset of postpartum luteal activity. Biology of Reproduction, Vol.45, No.3 (September 1991), pp. 514-522. ISSN 0006-3363

Williams, G.L.; Stanko, R.L. (2000). Dietary fats as reproductive nutraceuticals in cattle. Proceedings of the American Society for Animal Science 1998/1999. Journal of Animal Science, Vol.77, No.ESuppl (January 2000), pp. 1-12. ISSN 1525-3163

Williams, G.L. (1989). Modulation of luteal activity in postpartum beef cows through changes in dietary lipid. Journal of Animal Science, Vol.67, No.3 (March 1989); pp. 785-793. ISSN 1525-3163

Williams, G.L. \& Amstalden, M. (2010). Understanding postpartum anestrus and puberty in the beef female. Proceedings, Applied Reproductive Strategies in Beef Cattle. January 2829, 2010; San Antonio, TX. USA. 55-71 p.

Wonnacott, K.E.; Kwong, W.Y.; Hughes, J.; Salter, A.M.; Lea, R.G.; Garnsworthy, P.C. \& Sinclair, K.D. (2010). Dietary omega-3 and -6 polyunsaturated fatty acids affect the composition and development of sheep granulosa cells, oocytes and embryos. Reproduction, Vol.139, No.1 (January 2010), pp. 57-69. ISSN 1470-1626 
Wood, J.D.; Richardson, R.I.; Nute, G.R.; Fisher, A.V.; Campo, M.M.; Kasapidou, E.; Sheard, P.R. \& Enser, M. (2003). Effects of fatty acids on meat quality: a review. Meat Science, Vol.66, No.1 (January 2004), pp. 21-32. ISSN 0309-1740

Zeron, Y.; Sklan, D. \& Arav, A. (2002). Effect of polyunsaturated fatty acid supplementation on biophysical parameters and chilling sensitivity of ewe oocytes. Molecular Reproduction and Development, Vol.61, No.2 (February 2002), pp. 271-278. ISSN 10982795 


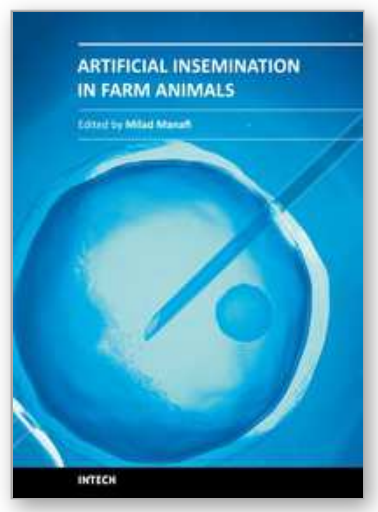

\author{
Artificial Insemination in Farm Animals \\ Edited by Dr. Milad Manafi
}

ISBN 978-953-307-312-5

Hard cover, 300 pages

Publisher InTech

Published online 21, June, 2011

Published in print edition June, 2011

Artificial insemination is used instead of natural mating for reproduction purposes and its chief priority is that the desirable characteristics of a bull or other male livestock animal can be passed on more quickly and to more progeny than if that animal is mated with females in a natural fashion. This book contains under one cover 16 chapters of concise, up-to-date information on artificial insemination in buffalos, ewes, pigs, swine, sheep, goats, pigs and dogs. Cryopreservation effect on sperm quality and fertility, new method and diagnostic test in semen analysis, management factors affecting fertility after cervical insemination, factors of noninfectious nature affecting the fertility, fatty acids effects on reproductive performance of ruminants, particularities of bovine artificial insemination, sperm preparation techniques and reproductive endocrinology diseases are described. This book will explain the advantages and disadvantages of using Al, the various methodologies used in different species, and how Al can be used to improve reproductive efficiency in farm animals.

\title{
How to reference
}

In order to correctly reference this scholarly work, feel free to copy and paste the following:

Jose Herrera-Camacho, Alejandra Soberano-Martinez, Karlos Edmundo Orozco Duran, Carlos Aguilar-Perez and Juan Carlos Ku-Vera (2011). Effect of Fatty Acids on Reproductive Performance of Ruminants, Artificial Insemination in Farm Animals, Dr. Milad Manafi (Ed.), ISBN: 978-953-307-312-5, InTech, Available from: http://www.intechopen.com/books/artificial-insemination-in-farm-animals/effect-of-fatty-acids-on-reproductiveperformance-of-ruminants

\section{INTECH}

open science | open minds

\section{InTech Europe}

University Campus STeP Ri Slavka Krautzeka 83/A

51000 Rijeka, Croatia

Phone: +385 (51) 770447

Fax: +385 (51) 686166

www.intechopen.com

\section{InTech China}

Unit 405, Office Block, Hotel Equatorial Shanghai

No.65, Yan An Road (West), Shanghai, 200040, China 中国上海市延安西路65号上海国际贵都大饭店办公楼 405 单元

Phone: +86-21-62489820

Fax: +86-21-62489821 
(C) 2011 The Author(s). Licensee IntechOpen. This chapter is distributed under the terms of the Creative Commons Attribution-NonCommercialShareAlike-3.0 License, which permits use, distribution and reproduction for non-commercial purposes, provided the original is properly cited and derivative works building on this content are distributed under the same license. 